\title{
(6) OPEN ACCESS \\ Exposure of hairdressers to ortho- and meta-toluidine in hair dyes
}

\author{
Gabriella M Johansson, ${ }^{1}$ Bo A G Jönsson, ${ }^{1}$ Anna Axmon, ${ }^{2}$ Christian H Lindh, ${ }^{2}$ \\ Marie-Louise Lind, ${ }^{3}$ Mats Gustavsson, ${ }^{2}$ Karin Broberg, ${ }^{2}$ Anders Boman, ${ }^{3}$ \\ Birgitta Meding, ${ }^{3}$ Carola Lidén, ${ }^{3}$ Maria Albin ${ }^{1}$
}

${ }^{1}$ Division of Occupational and Environmental Medicine, Department of Laboratory Medicine, Lund University, Lund, Sweden

${ }^{2}$ Department of Occupational and Environmental Medicine, University and Regional Laboratories Region Skåne, Lund, Sweden

${ }^{3}$ Institute of Environmental Medicine, Karolinska Institutet, Stockholm, Sweden

\section{Correspondence to}

Gabriella Johansson,

Division of Occupational and Environmental Medicine, SUS Lund, Lund SE-221 85, Sweden;

gabriella.johansson@med.lu.se

Received 31 October 2013 Revised 16 March 2014 Accepted 29 March 2014 Published Online First

9 June 2014
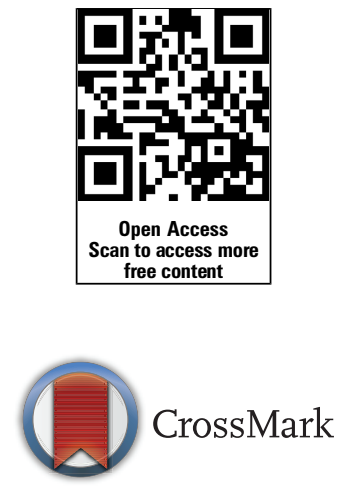

To cite: Johansson GM, Jönsson BAG, Axmon A, et al. Occup Environ Med 2015;72:57-63.

\section{ABSTRACT}

Background Carcinogenic aromatic amines derived from hair dyes have recently received new attention. One of these is ortho (o)-toluidine, which is classified as carcinogenic to humans.

Objectives To clarify exposure of hairdressers to potentially carcinogenic aromatic amines, including o-toluidine.

Methods We measured eight potentially carcinogenic aromatic amines in the blood of 295 hairdressers, 32 users of hair dyes and 60 controls. The study was restricted to female non-smokers. Lifestyle data were collected for all participants using self-administered questionnaires. Blood samples were taken for analysis of ortho-, meta (m)- and para (p)-toluidine; 2-, 3- and 4-ethylaniline, 2,3- and 3,4-dimethylaniline as haemoglobin adducts. The samples were analysed with gas chromatography-tandem mass spectrometry.

Results Generally, adduct concentrations were in the range of $0-200 \mathrm{pg} / \mathrm{g}$ haemoglobin. A comparison of the adduct concentrations found in hairdressers, consumers and controls showed no statistically significant differences. However, for hairdressers, 0 - and m-toluidine concentrations increased significantly with the weekly number of hair waving $(p=0.020)$ and permanent hair dyeing treatments $(p=0.026)$, respectively. o-Toluidine and $\mathrm{m}$-Toluidine concentrations also tended $(\mathrm{p}=0.076$ and 0.080 , respectively) to increase with the frequency of light-colour permanent hair dye treatments.

Conclusions Hairdressers who use light-colour permanent hair dyes, other permanent hair dyes and hair waving treatments seem to be exposed to 0 - and $\mathrm{m}$-toluidine as indicated by associations with the number of treatments performed. Analyses of hair waving and hair dye products should be performed to identify the possible sources of exposure to 0 - and m-toluidine.

\section{INTRODUCTION}

Based on an excess risk for urinary bladder cancer, ${ }^{1}$ hairdressing is classified as probably carcinogenic to humans (group 2A, IARC 2010). ${ }^{2}$ Hairdressers are believed to be exposed to bladder carcinogens from aromatic amines present in hair dyes. Similarly, personal use of permanent hair dyes (sometimes also referred to as oxidative hair dyes, semi-permanent hair dyes, intensive hair dyes, etc) has been reported to be associated with bladder cancer ${ }^{3}$ and also non-Hodgkin lymphoma (especially for use before 1980) and leukaemia. ${ }^{4}$ However, personal use of permanent hair dyes was assessed to be non-

\section{What this paper adds}

- Hairdressing work is classified as probably carcinogenic, based on an excess risk for bladder cancer. However, it is highly controversial if current work still entails exposure to carcinogens, or if this has been eliminated by restricting the use of several aromatic amines in hair dyes.

- The large individual variation in products used, skin absorption and short biological half-lives have challenged classic occupational hygiene assessment of hairdressers' exposure to aromatic amines. However, determination of haemoglobin adducts in blood provides a long-term exposure estimate for all routes of exposure.

- We found that hairdressers using permanent hair dye and hair waving products seem to be exposed to carcinogenic aromatic amines. Systematic screening of those products to identify the sources of exposure is indicated. Hairdressers should protect themselves from dermal uptake by using protective gloves, and perform work where gloves cannot easily be worn (like cutting the hair) before dyeing.

classifiable as a human cancer risk (group 3, IARC 2010). ${ }^{2}$ In the 1970 s, $89 \%$ of commercial hair dye formulations contained aromatic amines, which were mutagenic according to the Ames test. ${ }^{5}$ This led to restrictions in the formulations, and the toxicological documentation for hundreds of hair dye substances and several reaction products has been assessed by the Scientific Committee on Consumer Safety and its predecessors. ${ }^{6}$

The risk for bladder cancer among hairdressers and consumers of hair dyes has been investigated in many studies. ${ }^{3}{ }^{7-16}$ It has been claimed that this observed excess risk is caused by exposure that is not relevant to current hair dye products, since classified carcinogenic aromatic amines are now excluded. ${ }^{17}$ Toluidines, their isomers, salts and halogenated and sulfonated derivatives are prohibited in cosmetics in the EU. ${ }^{18}$ Nevertheless, studies that screened for the forbidden carcinogenic aromatic amines in commercial hair dye products found 4-aminobiphenyl at concentrations up to $12.8 \mathrm{ng} / \mathrm{g}$ 
in the USA ${ }^{19}$ and ortho (o)-toluidine in concentrations up to $1547 \mu \mathrm{g} / \mathrm{g}$ in Turkey. ${ }^{20}$ It is presently unclear if hairdressers and consumers are exposed to carcinogenic aromatic amines; this can, however, be monitored with haemoglobin ( $\mathrm{Hb}$ ) adducts.

The objective of this study was to monitor long-term exposure to one established carcinogen (o-toluidine) and seven suspected carcinogenic aromatic amines (meta $(\mathrm{m})$-, para (p)-toluidine, 2-, 3-, 4-ethylaniline (EA), 2,3- and 3,4-dimethylaniline (DMA)) as $\mathrm{Hb}$ adducts among hairdressers, consumers of hair dyes and controls. In addition, one commercial hair waving product was also analysed for o-, $\mathrm{m}$ - and p-toluidine.

\section{METHODS}

\section{Subjects and selection criteria}

We designed this cross-sectional study primarily to examine associations with intensity of use of different hair products and $\mathrm{Hb}$-adduct concentrations among the highest exposed groupthat is, the hairdressers, and thus, this group was the largest in our study. Additionally, for comparison of the levels of adducts, two smaller groups-people with personal use of hair dye products and a group of controls-were included to establish the background levels. All subjects selected were women, 1855 years of age, who had not used any tobacco product (including smokeless tobacco and occasional smoking) in the past 6 months. Smoking status was stated in the questionnaires for all subjects. To verify smoking status, cotinine (a biomarker for exposure to tobacco smoke) was measured in the urine of a subsample of $22 \%$ of the hairdressers. In total, 295 hairdressers, 32 consumers of hair dyes and 60 controls were recruited. The group-specific selection criteria for hairdressers were work as a hairdresser for at least 6 months, and for consumers regular treatment with permanent and/or semi-permanent hair dye (about every 8 weeks), while among the controls any use of hair dyes in the past year was an exclusion criterion.

Hairdressers were recruited during working hours by personal visits to hairdressing salons identified through telephone books in Lund (for the province of Scania) and Stockholm, Sweden. The study was explained, and hairdressers who fulfilled the criteria and agreed to participate were given questionnaires. An appointment for blood collection was also made. Hairdressers were asked to answer the questionnaire as it related to their work for the past 4 months. The hairdressers returned their questionnaires at the blood sampling appointment. Consumers and controls were staff recruited through advertisements in the local hospital areas and on the hospitals' intranets, and in Stockholm also on the university campus. Consumers and controls were seen at the outpatient clinics of the participating research units in Lund and Stockholm. Consumers were seen no later than 5 days after a hair dye treatment.

The subjects were recruited between 1 September 2008 and 1 June 2009. About half (146 subjects) of the study population was recruited from the province of Scania (in southern Sweden) and the remainder from the Stockholm area. For Scania, we specifically collected information on the inclusion process for the hairdressers (figure 1). This information was not available for the Stockholm area. The study was initiated after approval by the regional ethics committee at Lund University, and all study subjects in the province of Scania and Stockholm signed a written informed consent form.

\section{Questionnaire data and blood sampling}

The self-administered questionnaire consisted of three parts: (1) employment as a hairdresser, (2) other jobs/hobbies besides hairdressing and (3) lifestyle. The hairdressers were given all three parts to answer, while consumers and controls were given parts 2 and 3. A question about ever-working as a hairdresser was included in the consumers' and controls' questionnaire.

\section{Employment as hairdresser}

This part of the questionnaire focused on potential exposure to aromatic amines from different occupational sources such as:

- Treatments per week with light-colour permanent hair dye, all other permanent hair dye, intensive semi-permanent hair dye, semi-permanent hair dye, hair waving, bleaching and conditioning with pigment $(0,1-7,8-14,>15$ treatments/ week).

- Type of protective gloves used (vinyl/plastic, natural rubber latex, others or unknown to the hairdresser).

- Frequencies for use of gloves during permanent/semipermanent hair dyeing, highlighting and conditioning with pigment (never, sometimes or always; table 1).

- Change of gloves (after each work task, after each customer, daily, once a month or less often).
Figure 1 Source population and successful inclusion of 146 hairdressers recruited from the province of Scania (southern Sweden). * Others: hairdressers who were occupied with work or on sick leave during the first visit to the salon were given an information paper about the study and our contact information. None of these hairdressers contacted the clinic and they could thus not be classified according to the selection criteria.

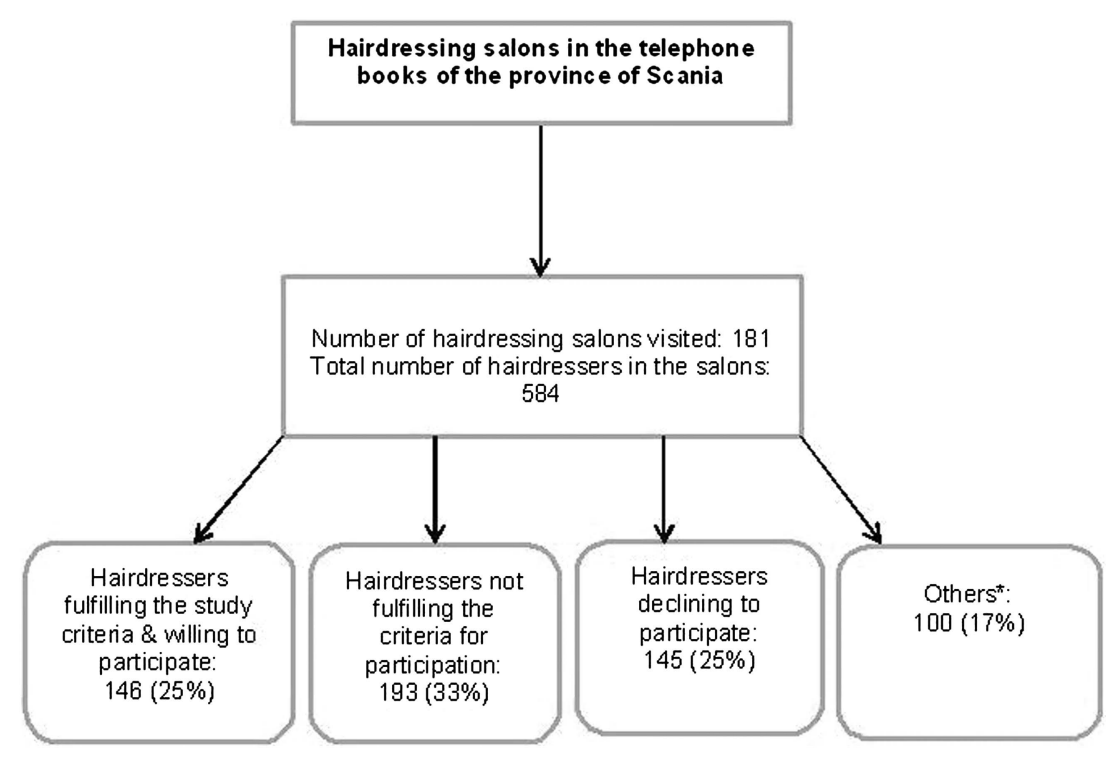


Table 1 Descriptive data for the hairdressers, consumers with personal hair dye use, and controls

\begin{tabular}{|c|c|c|c|c|c|c|c|}
\hline \multirow{2}{*}{$\begin{array}{l}\text { Descriptive data } \\
\text { Age, mean (SD) }\end{array}$} & & \multicolumn{2}{|c|}{ Hairdressers $(\mathrm{N}=295)$} & \multicolumn{2}{|c|}{ Consumers $(\mathrm{N}=32)$} & \multicolumn{2}{|c|}{ Controls $(\mathrm{N}=60)$} \\
\hline & & $38(10)$ & & $44(8)$ & & 35 & \\
\hline \multirow[t]{7}{*}{ Personal use of hair dyes, $\mathrm{N}(\%)$} & & Yes & No & Yes & No & Yes & No \\
\hline & Ever used permanent hair dye & $265(94)$ & $18(6)$ & $29(91)$ & $3(9)$ & NA & NA \\
\hline & Regular use of permanent hair dye & $183(69)$ & $84(31)$ & $15(60)$ & $10(40)$ & NA & NA \\
\hline & Ever used semi-permanent hair dye & $256(90)$ & $27(10)$ & $26(81)$ & $6(19)$ & NA & NA \\
\hline & Regular use of semi-permanent hair dye & $97(39)$ & $153(61)$ & $7(28)$ & $18(72)$ & NA & NA \\
\hline & Any use of permanent hair dye recent years & NA & NA & NA & NA & 0 & 60 \\
\hline & Any use of semi-permanent hair dye recent years & NA & NA & NA & NA & 0 & 60 \\
\hline \multirow[t]{2}{*}{ Working hours, $\mathrm{N}(\%)$} & $\begin{array}{l}\text { Full-time } \\
\text { Part-time }\end{array}$ & $\begin{array}{l}174(74) \\
60(26)\end{array}$ & & & & & \\
\hline & Treatment & Never & Sometimes & Always & & & \\
\hline Use of gloves, N (\%) & $\begin{array}{l}\text { Permanent hair dye } \\
\text { Highlights } \\
\text { Semi-permanent hair dye } \\
\text { Semi-permanent hair dye (foam) } \\
\text { Conditioning with pigment }\end{array}$ & $\begin{array}{l}0(0) \\
47(22) \\
6(3) \\
66(33) \\
95(48)\end{array}$ & $\begin{array}{l}14(7) \\
75(36) \\
32(15) \\
68(34) \\
58(30)\end{array}$ & $\begin{array}{l}198(93) \\
89(42) \\
171(82) \\
64(32) \\
43(22)\end{array}$ & & & \\
\hline Change of gloves, $\mathrm{N}(\%)$ & $\begin{array}{l}\text { After each work task } \\
\text { After each customer } \\
\text { Daily } \\
\text { Once a month } \\
\text { Less often }\end{array}$ & $\begin{array}{l}93(40) \\
81(35) \\
22(9) \\
26(11) \\
11(5)\end{array}$ & & & & & \\
\hline Type of protective gloves $\mathrm{N}(\%)$ & $\begin{array}{l}\text { Vinyl/plastic } \\
\text { Natural rubber latex } \\
\text { Others } \\
\text { Unknown }\end{array}$ & $\begin{array}{l}183(71) \\
58(23) \\
5(2) \\
10(4)\end{array}$ & & & & & \\
\hline
\end{tabular}

Note that consumers were required to have regular use of permanent or semi-permanent hair dyes, and controls not to have any such use during the past year. $\mathrm{NA}$, question not included in the questionnaire.

Other jobs/hobbies besides hairdressing

To rule out interference from other sources of occupational exposure, the subjects were asked questions about former or recent work (in the past 6 months) in textile dyeing, fingernail construction, rubber manufacturing, and about hobbies such as textile dyeing.

\section{Lifestyle}

In addition to occupational exposure, the hairdressers' exposure can be influenced by personal use of hair dyes. This parameter was included in the survey. Questions included personal use of permanent and/or semi-permanent hair dyes as well as passive smoking.

\section{Choice of biomarkers and sample preparation of haemoglobin adducts}

The selection of aromatic amines was based on former studies exploring exposure to these compounds. ${ }^{20} 21$ Aromatic amines were analysed as $\mathrm{Hb}$ adducts in blood. These reflect a long-term exposure since the lifespan of $\mathrm{Hb}$ is about 120 days. The eight adducts analysed in this study comprised three groups: o-, mand p-toluidine; 2-, 3- and 4-EA; 2,3- and 3,4-DMA. o-Toluidine is classified as carcinogenic to humans (group 1, International Agency for Research on Cancer (IARC)), ${ }^{22}$ $\mathrm{m}$-toluidine has been assessed as not classifiable as carcinogenic to humans owing to a lack of data (group A4, American Conference of Governmental Industrial Hygienists (ACGIH) $)^{23}$ and p-toluidine is classified as a confirmed animal carcinogen with unknown relevance to humans (group A3, ACGIH). ${ }^{23}$ 2-EA is suspected of causing cancer (hazard class carcinogen 2, European Chemicals Agency-classification, labelling and packaging (ECHA-CLP)). ${ }^{24}$ 3-, 4-EA and 2,3-, 3,4-DMA have no classification for cancer owing to the absence of data (ECHA-CLP). ${ }^{25}$

Blood was collected in two $8 \mathrm{~mL}$ heparinised tubes (BD Vacutainer) and separated into erythrocytes and plasma. The plasma was frozen at $-20^{\circ} \mathrm{C}$. The erythrocytes were washed three times with phosphate-buffered saline to remove unbound chemicals and stored in polypropylene tubes at $-20^{\circ} \mathrm{C}$ until analysis. The method used was developed by Skipper and Stillwell. $^{26}$ Some minor modifications of the protocol were made. Briefly, the samples were left to thaw for $30 \mathrm{~min}$ and then centrifuged for $20 \mathrm{~min}$. The supernatant, consisting of $\mathrm{Hb}$, was transferred to dialysis tubes (Sigma Aldrich). Dialysis was performed at $4^{\circ} \mathrm{C}$ for 3 days in ultrapure water, which was changed every day. Dialysed $\mathrm{Hb}(2 \mu \mathrm{L})$ was used to determine the concentration of $\mathrm{Hb}$ in the samples. For analysis of $\mathrm{Hb}$ adducts, $4 \mathrm{~mL}$ of dialysed $\mathrm{Hb}$ were transferred to $13 \mathrm{~mL}$ glass tubes and $100 \mathrm{pg}$ of four internal standards (o-, m-, p-toluidine $\mathrm{d}_{9}$ and 4 -EA $\mathrm{d}_{11}$ ) were added to all samples. The calibration curve ranged from 5 to $200 \mathrm{pg}$. The samples were hydrolysed with sodium hydroxide, shaken at room temperature for $3 \mathrm{~h}$ and then extracted with $8 \mathrm{~mL}$ of hexane and shaken. The procedure was repeated three times. The extracted hexane phase was transferred to glass tubes and sodium sulfate added to remove any excess water. After $2 \mathrm{~h}$, the hexane phase was transferred to new tubes and $10 \mu \mathrm{L}$ of trimethylamine, followed by $10 \mu \mathrm{L}$ of pentafluoropropionic acid, was added in the derivatisation step. The samples were shaken with $3 \mathrm{~mL}$ of phosphate buffer. The phosphate phase was discarded and the hexane phase evaporated under a stream of nitrogen gas until almost dry. Aliquots of $100 \mu \mathrm{L}$ of toluene were added and transferred to $2 \mathrm{~mL}$ dram vials.

A $2 \mu \mathrm{L}$ aliquot of the solution was injected into a gas chromatography-tandem mass spectrometry system (Varian $1200 \mathrm{~L})$. The results obtained from the instrumental analysis were in picograms and recalculated as $\mathrm{pg} / \mathrm{g} \mathrm{Hb}$.

The limit of detection (LOD) was determined for all compounds in $\mathrm{pg} / \mathrm{g} \mathrm{Hb}$ : o-toluidine (13.3), m-toluidine (16.6), p-toluidine (29.3), 2-EA (6.6), 3-EA (7.2), 4-EA (7.9), 2,3-DMA (4.2) and 3,4-DMA (17.9). 


\section{Analysis of a hair waving product}

One common commercial hair waving product was randomly chosen for analysis of $\mathrm{o}^{-}, \mathrm{m}$ - and $\mathrm{p}$-toluidine. The product consisted of three solutions: a perming lotion containing the hair waving ingredients ammonium thioglycolate and ammonium thiolactate; a fixative containing polyquaternium-7, which is a polyacrylamide; and a nourishing cream; all components contained several ingredients of unknown concentration in the product. The three solutions were analysed separately, and a mix of the perming lotion and fixative was also analysed. The concentrations obtained were expressed in nanograms/gram of the solution. The sample preparation was the same as for the $\mathrm{Hb}$ adducts except for the exclusion of dialysis and determination of $\mathrm{Hb}$ content. The calibration curve ranged from 0.5 to 20 ng.

\section{Statistical analysis}

To enable statistical analysis, samples below the LOD were assigned half the LOD value. The large fraction of concentrations below the LOD caused the data to be skewed. The use of non-parametric methods was thus considered the most appropriate. Differences in the median concentrations were tested with the Mann-Whitney U test. Since reference values are not available for the analysed compounds, hairdressers and consumers exceeding the 95th centile of the values for controls were classified as having high adduct concentrations. ${ }^{23}$ The fractions with high versus lower adduct concentrations in the three exposure groups were compared using binary logistic regression to estimate ORs with $95 \%$ CIs for having high adduct concentrations.

Further analyses included comparisons of the adduct concentrations within the hairdressers group based on questionnaire data. Increasing number of treatments per week, frequencies for use of gloves and change of gloves were compared with adduct concentrations using the Jonckheere-Terpestra test for trend. Categories with fewer than five cases were included in the adjacent category. Spearman's rank correlation test was used to test the correlation between adducts and treatments per week.

\section{RESULTS}

Descriptive data for the study population are provided in table 1 . The median age differed somewhat between the exposure groups, with consumers being somewhat older (44 years) than hairdressers ( 38 years) and controls (35 years). The personal use of hair dyes was similar between hairdressers and consumers. Most hairdressers and consumers had ever used both permanent and semi-permanent hair dyes. The majority in both groups used permanent hair dye regularly. Most hairdressers worked full-time (74\%). An overview of the $\mathrm{Hb}$-adduct concentrations for hairdressers, consumers and controls, respectively, is presented in table 2 .

Overall, no statistically significant differences were found between the groups. Among consumers, as reflected in the ORs (range $\mathrm{OR}=1.27-1.97$ compared with controls), the fraction with high concentrations was somewhat larger than among controls for each adduct; however, the few observations above the LOD are reflected in imprecise point estimates.

Comparisons within the group were performed for hairdressers. Frequencies (number/week) of treatments performed with light-colour permanent hair dye, other permanent hair dye, intensive semi-permanent hair dye, semi-permanent hair dye, hair waving, bleaching and conditioning with pigment per week were compared with adduct concentrations (table 3 ).

$\mathrm{o}$-Toluidine and $\mathrm{m}$-toluidine $\mathrm{Hb}$-adduct concentrations increased with the number of treatments per week of lightcolour permanent hair dye; however, this was not statistically significant. The m-toluidine concentrations increased significantly with the other permanent hair dye treatments performed $(p=0.026)$. For o-toluidine, a significant difference was found for hairdressers performing hair waving each week compared with those who did not, with higher concentrations found among those waving hair $\geq 1-7$ times/week $(p=0.020)$. Significantly lower exposure concentrations were found for 2,3-DMA (hair waving) and p-toluidine (conditioning with pigment) among hairdressers using the treatments $\geq 1-7$ times/week compared with 0 treatments/week. No effects were found for shades, use of gloves, change of gloves and type of gloves used $(p>0.05)$.

Hairdressers' and consumers' personal use of hair dye was analysed, but did not affect concentrations of the assessed $\mathrm{Hb}$ adducts $(p>0.05)$. Neither did other jobs/hobbies (jobs in textile dyeing, fingernail construction, rubber manufacturing and hobbies such as textile dyeing) affect the $\mathrm{Hb}$-adduct concentrations. A positive correlation was found between adduct concentrations of $\mathrm{o}-$ and $\mathrm{m}$-toluidine $\left(\mathrm{r}_{\mathrm{s}}=0.29, \mathrm{p}=0.004\right)$. No such correlations were seen for the other adducts. Positive correlations were seen for all treatments performed per week (data not shown).

Table 2 Concentrations of haemoglobin $(\mathrm{Hb})$ adducts among hairdressers, consumers and controls

\begin{tabular}{|c|c|c|c|c|c|c|c|}
\hline $\mathrm{Hb}$ adduct & Group & $\begin{array}{l}\text { Samples >LOD* } \\
(n, \%)\end{array}$ & $\begin{array}{l}\text { Median } \\
\text { (pg/g Hb) }\end{array}$ & p Valuet & $\begin{array}{l}\text { 95th Centile } \\
\text { (pg/g Hb) }\end{array}$ & $\begin{array}{l}\text { Highғ } \\
\mathbf{n}(\%)\end{array}$ & $\begin{array}{l}\text { OR (Cl) for high } \\
\text { Hb-adduct concentration§ }\end{array}$ \\
\hline o-Toluidine & $\begin{array}{l}\text { Hairdresser } \\
\text { Consumer } \\
\text { Control }\end{array}$ & $\begin{array}{r}168(57) \\
15(47) \\
34(57)\end{array}$ & $\begin{array}{r}18 \\
7 \\
14\end{array}$ & $\begin{array}{l}0.50 \\
0.81\end{array}$ & $\begin{array}{r}320 \\
290 \\
60\end{array}$ & $\begin{array}{r}27(9) \\
2(6) \\
3(5)\end{array}$ & $\begin{array}{c}1.91 \text { (0.56 to } 6.5) \\
1.27 \text { (0.20 to } 8.0) \\
1.0 \text { (Reference) }\end{array}$ \\
\hline m-Toluidine & $\begin{array}{l}\text { Hairdresser } \\
\text { Consumer } \\
\text { Control }\end{array}$ & $\begin{array}{r}288(98) \\
31(97) \\
58(97)\end{array}$ & $\begin{array}{l}180 \\
180 \\
190\end{array}$ & $\begin{array}{l}0.51 \\
0.62\end{array}$ & $\begin{array}{l}330 \\
440 \\
370\end{array}$ & $\begin{array}{r}12(4) \\
2(6) \\
3(5)\end{array}$ & $\begin{array}{c}0.81(0.22 \text { to } 2.9) \\
1.27 \text { (0.20 to } 8.0) \\
1.0 \text { (Reference) }\end{array}$ \\
\hline p-Toluidine & $\begin{array}{l}\text { Hairdresser } \\
\text { Consumer } \\
\text { Control }\end{array}$ & $\begin{array}{r}241(82) \\
27(84) \\
53(88)\end{array}$ & $\begin{array}{l}80 \\
90 \\
70\end{array}$ & $\begin{array}{l}0.62 \\
0.16\end{array}$ & $\begin{array}{l}210 \\
240 \\
210\end{array}$ & $\begin{array}{r}14(5) \\
3(9) \\
3(5)\end{array}$ & $\begin{array}{l}0.95 \text { (0.26 to } 3.4) \\
1.97 \text { (0.37 to } 10.4) \\
1.0 \text { (Reference) }\end{array}$ \\
\hline 2,3-DMA & $\begin{array}{l}\text { Hairdresser } \\
\text { Consumer } \\
\text { Control }\end{array}$ & $\begin{array}{l}259(88) \\
28(88) \\
60(100)\end{array}$ & $\begin{array}{l}30 \\
30 \\
40\end{array}$ & $\begin{array}{l}0.028 \\
0.098\end{array}$ & $\begin{array}{l}220 \\
550 \\
380\end{array}$ & $\begin{array}{l}8(3) \\
2(6) \\
3(5)\end{array}$ & $\begin{array}{c}0.53 \text { (0.14 to } 2.1) \\
1.27 \text { (0.20 to } 8.0) \\
1.0 \text { (Reference) }\end{array}$ \\
\hline
\end{tabular}

${ }^{*}$ For $0-, \mathrm{m}$ - and p-toluidine, and 2,3-DMA, $<50 \%$ of samples were below the LOD. For the remaining adducts, $>50 \%$ of the samples were below LOD and are not presented.

tp Value (Mann-Whitney $U$ test) for the median concentration of hairdressers and consumers, respectively, compared with the control group.

¥High is here defined as samples exceeding the 95th centile of the controls' concentrations.

§ORs, with $95 \% \mathrm{Cls}$, for high concentrations obtained through binary logistic regression.

DMA, dimethylaniline; LOD, limit of detection. 
Table 3 Frequencies of performed treatments in comparison with haemoglobin ( $\mathrm{Hb})$ adduct concentrations among hairdressers

\begin{tabular}{|c|c|c|c|c|c|c|}
\hline \multirow[b]{2}{*}{ Treatment } & \multirow{2}{*}{\multicolumn{2}{|c|}{ Performed treatments/week $(\mathrm{N})$ * }} & \multicolumn{4}{|c|}{ Haemoglobin adducts (median, pg/g Hb) } \\
\hline & & & o-Toluidine & m-Toluidine & p-Toluidine & 2,3-DMA \\
\hline \multirow[t]{4}{*}{ Light-colour permanent hair dye } & $0(32)$ & & 7 & 162 & 72 & 30 \\
\hline & $1-7(219)$ & & 19 & 178 & 75 & 29 \\
\hline & $\begin{array}{l}8-14(39) \\
>15(3)\end{array}$ & $\geq 8$ Treatments (42) & 22 & 184 & 84 & 32 \\
\hline & $\mathrm{p}$ Value & & 0.076 & 0.080 & 0.34 & 0.59 \\
\hline \multirow[t]{4}{*}{ Other permanent hair dye } & $\begin{array}{l}0(0) \\
1-7(194)\end{array}$ & $\geq 0-7(194)$ & 14 & 172 & 76 & 30 \\
\hline & $8-14(88)$ & & 21 & 190 & 81 & 28 \\
\hline & $>15(10)$ & & 14 & 186 & 73 & 28 \\
\hline & $\mathrm{p}$ Value & & 0.46 & 0.026 & 0.73 & 0.41 \\
\hline \multirow[t]{4}{*}{ Intensive semi-permanent hair dye } & $0(12)$ & & 7 & 193 & 128 & 24 \\
\hline & $1-7(227)$ & & 18 & 176 & 76 & 30 \\
\hline & $\begin{array}{l}8-14(47) \\
>15(4)\end{array}$ & $\geq 8$ Treatments (51) & 20 & 185 & 74 & 28 \\
\hline & p Value & & 0.32 & 0.50 & 0.23 & 0.59 \\
\hline \multirow[t]{4}{*}{ Semi-permanent hair dye } & $0(93)$ & & 15 & 181 & 74 & 29 \\
\hline & $1-7(165)$ & & 16 & 175 & 76 & 31 \\
\hline & $\begin{array}{l}8-14(28) \\
>15(3)\end{array}$ & $\geq 8$ Treatments $(31)$ & 22 & 185 & 82 & 23 \\
\hline & $\mathrm{p}$ Value & & 0.79 & 0.81 & 0.90 & 0.81 \\
\hline \multirow[t]{3}{*}{ Hair waving } & $0(156)$ & & 14 & 182 & 76 & 31 \\
\hline & $\begin{array}{l}1-7(136) \\
8-14(2) \\
>15(1)\end{array}$ & $\geq 1$ Treatments (139) & 22 & 176 & 76 & 27 \\
\hline & $p$ Value & & 0.020 & 0.19 & 0.94 & 0.020 \\
\hline \multirow[t]{3}{*}{ Bleaching } & $\begin{array}{l}0(3) \\
1-7(220)\end{array}$ & $\geq 0-7(223)$ & 17 & 176 & 77 & 30 \\
\hline & $\begin{array}{l}8-14(66) \\
>15(6)\end{array}$ & $\geq 8$ Treatments $(72)$ & 20 & 186 & 73 & 26 \\
\hline & p Value & & 0.69 & 0.35 & 0.56 & 0.29 \\
\hline \multirow[t]{5}{*}{ Conditioning with pigment } & $0(111)$ & & 13 & 178 & 83 & 28 \\
\hline & $1-7(129)$ & & 20 & 176 & 66 & 33 \\
\hline & $8-14(25)$ & & 19 & 179 & 75 & 30 \\
\hline & $>15(14)$ & & 14 & 180 & 75 & 18 \\
\hline & p Value & & 0.13 & 0.55 & 0.027 & 0.26 \\
\hline
\end{tabular}

\section{Analysis of a commercial hair waving product}

The perming lotion and nourishing cream did not contain any toluidines; however, the fixative and the mixed perming lotion + fixative contained o- and m-toluidines (table 4).

The concentration of o-toluidine was highest in the fixative (sample preparations 1 and 2 had 0.27 and $0.23 \mathrm{ng} / \mathrm{g}$, respectively). When mixed half/half with perming lotion+fixative the concentration of o-toluidine decreased (sample preparations 1 and 2 had 0.17 and $0.12 \mathrm{ng} / \mathrm{g}$, respectively). During hair waving, the whole bottle of fixative is used and the total exposure on the head amounts to 21.6 and $18 \mathrm{ng}$ o-toluidine for samples 1 and 2, respectively.

$\mathrm{m}$-Toluidine was also found in the fixative (sample preparation 1: $0.06 \mathrm{ng} / \mathrm{g}$; preparation $2: 0.15 \mathrm{ng} / \mathrm{g}$ ), and in the mixed fixative+perming lotion ( 0.01 and $0.02 \mathrm{ng} / \mathrm{g}$, respectively). The total exposure to m-toluidine during one hair waving treatment corresponds to 1.0 and $1.4 \mathrm{ng}$ m-toluidine for samples 1 and 2, respectively. p-Toluidine was not detected in any of the three parts of the product.

\section{DISCUSSION}

This first study of amine adducts in hairdressers and consumers identified an increase in $\mathrm{O}^{-}$and m-toluidine $\mathrm{Hb}$-adduct concentrations among hairdressers, associated with the weekly number of hair dye and hair waving treatments performed. The latter was somewhat unexpected, but analysis of a common randomly chosen product confirmed the presence of both o- and

Table 4 Concentrations (ng/g solution) of o-, m- and p-toluidine in one hair waving product

\begin{tabular}{|c|c|c|c|}
\hline Solution & $\begin{array}{l}\text { o-Toluidine } \\
\text { (ng/g) }\end{array}$ & $\begin{array}{l}\text { m-Toluidine } \\
\text { (ng/g) }\end{array}$ & $\begin{array}{l}\text { p-Toluidine } \\
\text { (ng/g) }\end{array}$ \\
\hline Perming lotion & ND & ND & ND \\
\hline Nourishing cream & ND & ND & ND \\
\hline \multicolumn{4}{|l|}{ Fixative } \\
\hline 1st Preparation & 0.27 & 0.06 & ND \\
\hline 2nd Preparation & 0.23 & 0.15 & ND \\
\hline \multicolumn{4}{|c|}{ Perming lotion+fixative } \\
\hline 1st Preparation & 0.17 & 0.01 & ND \\
\hline 2nd Preparation & 0.12 & 0.02 & ND \\
\hline \multicolumn{4}{|c|}{$\begin{array}{l}\text { The product consisted of three solutions: a perming lotion containing the hair } \\
\text { waving ingredients ammonium thioglycolate and ammonium thiolactate; a fixative } \\
\text { containing polyquaternium-7-that is, a polyacrylamide; and a nourishing cream; all } \\
\text { components contained several ingredients of unknown concentration in the product. } \\
\text { ND, not detected. }\end{array}$} \\
\hline
\end{tabular}


m-toluidine. Hairdressers use a variety of different hair dye products and our results indicate that the sources for o-toluidine $\mathrm{Hb}$ adducts may be specific products of light-colour permanent hair dyes and hair waving. In a Turkish study, 54 commercial permanent hair dyes were analysed. The variation in o-toluidine concentrations in different products of the same shade were in some cases 100-fold for dark-yellow permanent hair dye and approximately 500 -fold for black hair dyes. The same trend in variation was seen for $\mathrm{m}$ - and $\mathrm{p}$-toluidine concentrations in permanent hair dyes. This indicates that there is a high variation between products and further supports our findings that high o-toluidine adduct concentrations may originate from specific products. This might explain why toluidine adducts differ between different treatments. ${ }^{20}$

It is not possible to estimate the exposure in the general population owing to lack of data for o-toluidine in air, drinking water and foodstuffs. In occupational settings, exposure to o-toluidine comes from manufacture of dyestuffs, production of synthetic rubber, pesticides and epoxy resin systems. ${ }^{27} \mathrm{~A}$ recent cohort study considered o-toluidine to be responsible for the increased bladder cancer incidence among workers at a chemical manufacturing plant. ${ }^{28} \mathrm{Hb}$ adducts of toluidines in smokers versus non-smokers have been measured previously. ${ }^{29} 30$ The results showed that smokers have significantly higher o- and p-toluidine concentrations than non-smokers, but no significant differences were seen for m-toluidine. In comparison with our measured toluidine adduct concentrations, the adduct concentrations of non-smokers were about 10 times higher for o- and $\mathrm{m}$-toluidine. Possible explanations for this might be differences in gender, age, residency and year of sampling. These studies show that toluidines also originate from sources other than tobacco smoke. To further verify our study population as nonsmokers, cotinine, a metabolite of nicotine, was measured in the urine of a subsample of the hairdressers stratified according to o-toluidine adduct concentrations. The results showed that one of the hairdressers was a smoker; however, exclusion of this subject did not change the results.

The highest concentrations of adducts measured in this study, found in all three groups, were those of m-toluidine, with no significant differences between the groups. Dietary exposure to m-toluidine from herbicides ${ }^{31}$ may contribute to a background level in the population. However, the internal analyses within the hairdresser group also indicate a contribution from permanent hair dyes ('other', and possibly also 'light colour'). Surprisingly, p-toluidine concentrations decreased with increasing treatments of conditioning with pigment. No correlations between these and others treatments were seen. It might be a chance finding. However, as mentioned earlier, differences in p-toluidine concentrations between products, used for the same purpose, will introduce misclassification of exposure, which might bias the observed associations.

2-, 3-, 4-EA and 2,3-, 3,4-DMA were included in this study as results from an earlier study measured these adducts among patients with bladder cancer and controls, respectively. The authors stated that exposure to diverse aromatic amines is strongly associated with the risk of bladder cancer among nonsmokers. ${ }^{21}$ However, adduct concentrations of these amines in our study were very low, and for all adducts, except 2,3-DMA, less than $50 \%$ had detectable levels. Probably, these amines originate from exposure sources other than hair dyes. Our findings suggest that this is the case also for 2,3-DMA since the median adduct concentrations were significantly lower in hairdressers than among controls and negatively associated with hair waving treatments. Also, a tendency towards lower levels was seen among the consumers. A study measuring both exposure to aromatic amines and product analysis for the same amines would strengthen the conclusions about hairdressers' exposure to carcinogenic aromatic amines, and is encouraged. We took into account personal use of hair dyes and other jobs/hobbies, but these did not influence the levels of o-, $\mathrm{m}$ - and p-toluidine and 2,3-DMA.

\section{Methodological limitations}

$\mathrm{Hb}$ adducts are the best method for monitoring long-term exposure to aromatic amines because the lifetime of $\mathrm{Hb}$ is about 4 months and because of the close relationship with DNA adducts. ${ }^{32}$ Unfortunately, the sample preparation of $\mathrm{Hb}$ adducts is time consuming and involves several steps, introducing possible sources of error. Genetic factors also affect the metabolism of aromatic amines and, consequently, the adduct levels. ${ }^{33}$

In our study, analysis of $\mathrm{Hb}$ adducts of 2-, 3-, 4-EA and 3,4-DMA showed low adduct concentrations and the medians coincided with LOD values, resulting in a loss of samples for statistical analysis. Probably, these amines come from exposure sources other than hair dyes.

We chose to include a large number of hairdressers in the study in order to study dose-response associations, which was successful, and a fairly high number of controls to reliably establish background levels in the population. We had expected a rather small number of consumers to be sufficient, but the many samples lost to statistical analysis owing to high LODs reduced our ability to reach a conclusion about exposure due to personal hair dye use. Exposure monitoring with $\mathrm{Hb}$ adducts among hairdressers is highly dependent on proper questionnaire data. Categorical data must have enough sensitivity to be able to detect differences between the categories. Our descriptive data indicate that use of treatments/week of light-colour permanent hair dyeing, other permanent hair dyeing, intensive semipermanent hair dyeing, semi-permanent hair dyeing, hair waving, bleaching and conditioning with pigment should have been divided into several categories since most hairdressers performed the treatments 0 or 1-7 times/week.

In addition to exposure monitoring and questionnaire design, the selection of study subjects is crucial. We have no reason to believe that the non-participants - that is, women who were invited to the study but declined participation, differed substantially in their choice of products, use of treatments per week or safety precautions. Unfortunately, information on inclusion was only available for Scania. We have no reason to believe that there were any major differences in the inclusion process between Scania and Stockholm.

Apart from the potentially carcinogenic effects, a large proportion of hair dye substances are known to be very potent skin sensitisers. They cause contact allergy and hand eczema in hair dressers and eczema on head, face and neck in consumers. The permanent hair dye products on the market, light as well as dark shades, contain several hair dye substances, many of which are aromatic amines. ${ }^{34} 35$ Quantitative analysis of some skinsensitising hair dye substances in professional hair dye products indicates that they contain largely the same substances, while the concentrations generally are lower in light shades ${ }^{36}{ }^{37}$; however, analysis of the forbidden aromatic amines o-, $\mathrm{m}-$ and p-toluidine in commercial hair dyes shows an in-between product variation for both light and dark shades. ${ }^{20}$

\section{CONCLUSIONS}

We evaluated the exposure to eight selected potentially carcinogenic aromatic amines among hairdressers, consumers and 
controls, and found no overall significant difference between groups. However, adduct concentrations of o-toluidine among hairdressers significantly increased with the number of treatments per week of hair waving, as did the concentration of $\mathrm{m}$-toluidine with the number of treatments per week of permanent hair dying. A trend for higher concentrations of $\mathrm{o}^{-}$and m-toluidine was seen with increased use of light-colour permanent hair dye per week. Analysis of a hair waving product also confirmed the presence of o-toluidine.

$\mathrm{p}$-Toluidine adduct concentrations significantly decreased with the number of treatments per week of conditioning with pigment and hair waving. An in-between product variation of amine content may explain the different trends in adduct concentrations between the treatments.

Among consumers of hair dyes, high exposure concentrations to all adducts were found but the ORs were not significant, probably owing to the small sample size. The limits of detection coincided with the median concentrations for several of the analysed adducts; probably, these amines originate from other exposure sources.

Future studies should focus on finding exposure sources of oand m-toluidine in products used by hairdressers. Additional exposure monitoring studies among hairdressers and consumers are also encouraged, and in relation to genetic damage.

Acknowledgements We gratefully acknowledge the skilful assistance of Else-Marie Åkerberg, Eva Assarsson, Agneta Kristensen, Stina Johnsson and Eva Thunberg in the field work.

Contributors MA, BAGJ, CHL and KB designed the study. GMJ and M-LL were responsible for the field work. GMJ, MG, CHL and BAGJ developed the method. GMJ conducted the laboratory work. GMJ and MG evaluated the laboratory data. Statistical data was analysed by GMJ, $A A$ and interpreted by GMJ, $A A$ and MA. GMJ wrote the manuscript. MA, BAGJ, KB, CL, BM and $A B$ made a critical revision of the manuscript. All authors read and approved the final version of the manuscript.

Funding The project was supported by grants from the Swedish Council for Working life and Social Research and by FAS-centre Metalund. (2008-0071).

Competing interests None.

Patient consent Obtained

Ethics approval The study was approved by the regional ethics committee at Lund University.

Provenance and peer review Not commissioned; externally peer reviewed.

Open Access This is an Open Access article distributed in accordance with the Creative Commons Attribution Non Commercial (CC BY-NC 3.0) license, which permits others to distribute, remix, adapt, build upon this work non-commercially, and license their derivative works on different terms, provided the original work is properly cited and the use is non-commercial. See: http://creativecommons.org/ licenses/by-nc/3.0/

\section{REFERENCES}

1 Harling M, Schablon A, Schedlbauer G, et al. Bladder cancer among hairdressers: a meta-analysis. Occup Environ Med 2010;67:351-8.

2 International Agency for Research on Cancer, World Health Organization. Occupational exposures of hairdressers and barbers and personal use of hair colourants; some hair dyes, cosmetic colourants, industrial dyestuffs and aromatic amines. IARC Monogr Eval Carcinog Risks Hum 1993;57:5.

3 Koutros S, Silverman DT, Baris D, et al. Hair dye use and risk of bladder cancer in the New England bladder cancer study. Int I Cancer 2011;129:2894-904.

4 Miligi L, Costantini AS, Benvenuti A, et al. Personal use of hair dyes and hematolymphopoletic malignancies. Arch Environ Occup Health 2005;60:249-56.

5 Ames BN, Kammen HO, Yamasaki E. Hair dyes are mutagenic-identification of a variety of mutagenic ingredients. Proc Natl Acad Sci USA 1975;72:2423-7.

6 Scientific Committee on Consumer Safety, (SCCS). http://ec.europa.eu/health/ scientific_committees/consumer_safety/index_en.htm (accessed 24 Oct 2013).

7 Gaertner RRW, Trpeski L, Johnson KC, et al. A case-control study of occupational risk factors for bladder cancer in Canada. Cancer Causes Control 2004;15:1007-19.

8 Kogevinas M, Fernandez F, Garcia-Closas M, et al. Hair dye use is not associated with risk for bladder cancer: evidence from a case-control study in Spain. Eur $J$ Cancer 2006:42:1448-54.
9 Andrew AS, Schned AR, Heaney JA, et al. Bladder cancer risk and personal hair dye use. Int J Cancer 2004;109:581-6.

10 Lin J, Dinney CP, Grossman HB, et al. Personal permanent hair dye use is not associated with bladder cancer risk: evidence from a case-control study. Cancer Epidemiol Biomarkers Prev 2006;15:1746-9.

11 Ros MM, Gago-Dominguez M, Aben KKH, et al. Personal hair dye use and the risk of bladder cancer: a case-control study from The Netherlands. Cancer Causes Control 2012:23:1139-48.

12 Espinoza $F$, Silverman $D$, Kogevinas $M$, et al. Micronuclei assessment in the urothelial cells of women using hair dyes and its modulation by genetic polymorphisms. Cancer Lett 2008;263:259-66.

13 Ambrosone CB, Abrams SM, Gorlewska-Roberts K, et al. Hair dye use, meat intake, and tobacco exposure and presence of carcinogen-DNA adducts in exfoliated breast ductal epithelial cells. Arch Biochem Biophys 2007;464:169-75.

14 Skov T, Andersen $\mathrm{A}$, Malker $\mathrm{H}$, et al. Risk for cancer of the urinary-bladder among hairdressers in the nordic countries. Am J Ind Med 1990;17:217-23.

15 Skipper PL, Tannenbaum SR, Ross RK, et al. Nonsmoking-related arylamine exposure and bladder cancer risk. Cancer Epidemiol Biomarkers Prev 2003:12:503-7.

16 Czene K, Tiikkaja S, Hemminki K. Cancer risks in hairdressers: assessment of carcinogenicity of hair dyes and gels. Int J Cancer 2003;105:108-12.

17 Bolt HM, Golka K. The debate on carcinogenicity of permanent hair dyes: new insights. Crit Rev Toxicol 2007;37:521-36.

18 European Commission, Health and Consumers, Cosmetics-CosIng. Substance: Toluidines, their isomers, salts and halogenated and sulphonated derivates. http:/l ec.europa.eu/consumers/cosmetics/cosing/index.cfm?fuseaction=search.details v2\&id=28869 (accessed 23 Oct 2013)

19 Turesky RJ, Freeman JP, Holland RD, et al. Identification of aminobiphenyl derivatives in commercial hair dyes. Chem Res Toxicol 2003;16:1162-73.

20 Akyuz M, Ata S. Determination of aromatic amines in hair dye and henna samples by ion-pair extraction and gas chromatography-mass spectrometry. J Pharm Biomed Anal 2008:47:68-80.

21 Gan JP, Skipper PL, Gago-Dominguez M, et al. Alkylaniline-hemoglobin adducts and risk of non-smoking-related bladder cancer. I Nat/ Cancer Inst 2004:96:1425-31.

22 International Agency for Research on Cancer. Some industrial chemicals o-toluidine. IARC Monogr Eval Carcinog Risks Hum 2000;77:267-322.

23 American Conference of Governmental Industrial Hygienists, ACGIH: TLVs and BEls based on the documentation of the threshold limit values for chemical substances and physical agents \& biological exposure indices. ACGIH Worldwide 2003, 57.

24 European Chemicals Agency. Chemicals and Labelling. http://clp-inventory.echa. europa.eu/DetailsOfNotifAndLabelling.aspx?SubstancelD=109446\&NotificationID= 17841821 (accessed 19 Feb 2014).

25 European Chemicals Agency. Chemicals and Labelling. http://echa.europa.eu (accessed 19 Feb 2014).

26 Skipper PL, Stillwell WG. Aromatic amine-hemoglobin adducts. Methods in Enzymology; Hemoglobins, Part B: Biochemical and analytical methods. Methods Enzymol 1994:231:643-9.

27 World Health Organization. Concise international chemical assessment document 7, o-toluidine. WHO Library Cataloguing in Publication Data, 1998.

28 Carreon T, Hein MJ, Hanley KW. Bladder cancer incidence among workers exposed to o-toluidine, aniline and nitrobenzene at a rubber chemical manufacturing plant. Occup Environ Med 2014;71:175-82.

29 Bryant MS, Vineis P, Skipper PL, et al. Hemoglobin adducts of aromatic amines: associations with smoking status and type of tobacco. Proc Natl Acad Sci USA 1988;86:9788-91.

30 Branner B, Kutzer C, Zwickenpflug W, et al. Haemoglobin adducts from aromatic amines and tobacco-specific nitrosamines in pregnant smoking and non-smoking women. Biomarkers 1998:3:35-47.

31 Schettgen T, Weiss T, Angerer J. Biological monitoring of phenmedipham: determination of $\mathrm{m}$-toluidine in urine. Arch Toxicol 2001;75:145-9.

32 Dallinga JW, Pachen D, Wijnhoven SWP, et al. The use of 4-aminobiphenyl hemoglobin adducts and aromatic DNA adducts in lymphocytes of smokers as biomarkers of exposure. Cancer Epidemiol Biomarkers Prev 1998;7:571-7.

33 Skipper PL, Kim MY, Sun HLP, et al. Monocyclic aromatic amines as potential human carcinogens: old is new again. Carcinogenesis 2010;31:50-8.

34 Yazar K, Boman A, Liden C. Potent skin sensitizers in oxidative hair dye products on the Swedish market. Contact Dermatitis 2009;61:269-75.

35 Yazar K, Boman A, Liden C. p-Phenylenediamine and other hair dye sensitizers in Spain. Contact Dermatitis 2012;66:27-32.

36 Hamann D, Yazar K, Hamann CR, et al. p-Phenylenediamine and other allergens in hair dye products in the United States: a consumer exposure study. Contact Dermatitis 2014;70:213-18.

37 Danish Environmental Protection Agency. Survey and occurrence of PPD, PTD and other allergenic hair dye substances in hair dyes. Survey of Chemicals in Consumer Products No 121, 2013. http://www.mst.dk/ Publikationer/Publikationer/2013/Februar/978-87-92903-91-4.htm (accessed 24 Oct). 